\title{
University News/Nouvelles des universités
}

\section{Alberta \\ Forest Industry Lecture}

Mr. Mike Apsey, President, Council of Forest Industries delivered the 22nd Forest Industry Lecture in March. Copies of Mike's talk, entitled "New Dimensions in the development of forest policy: Lessons from the trenches" is available on request through the Department of Forest Science.

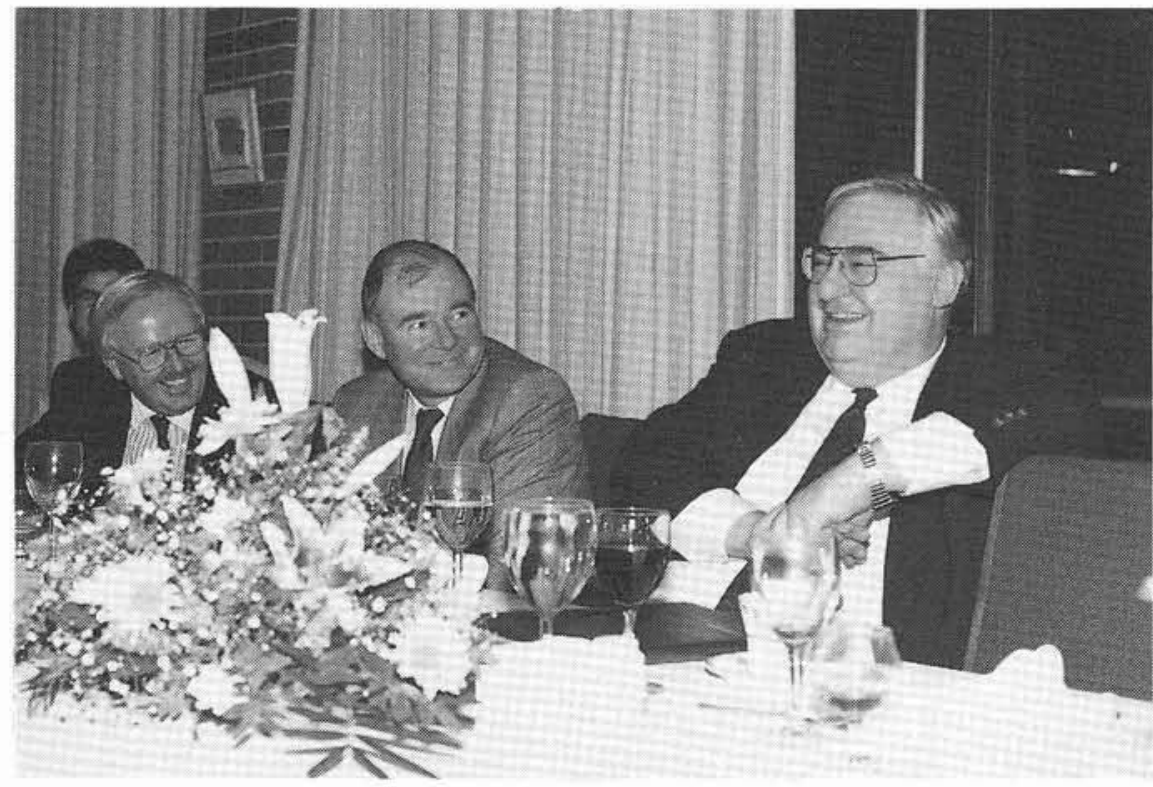

Mr. Fred McDougall (middle) Deputy Minister, of Forestry, Lands and Wildife and Ed Tyrchniewicz, (left) Dean, Faculty of Agriculture and Forestry attended the banquet in honor of FILS' guest speaker Mike Apsey.

\section{Des Crossley Memorial Scholarship:}

Mrs. Isobel Crossley was on hand at the recent FILS banquet to present the very first Desmond I. Crossley Memorial Scholarship. Mr. Robert A. Wright was the 1989 recipient of the $\$ 1500$ cash award. The Scholarship will be awarded annually to a graduate student in the Faculty of Agriculture and Forestry with particular interest in forest management or silviculture.

A native of Saskatchewan, Rob is a Ph.D. student in the Department of Forest Science working on Ecological Genetics of Seedling Drought Resistance in Jack Pine. Earning an 8.67 grade point average throughout his course work, he maintains a strong interest in the spatial and temporal scale of genetic and ecological differentiation between populations.

\section{CIF Gold Medal Winner:}

Ms. Caroline A. Kutash is the University of Alberta recipient of the 1989 Canadian Institute of Forestry Gold Medal Award.

Caroline was born and raised in Edmonton. She attended Harry Ainlay Composite High School and graduated in 1985 with a grade point average of $90.8 \%$. During her pursuit of a B.Sc. in Forestry, Caroline was the recipient of seven student scholarships and bursaries including the Herbert and Jeannette Hall Scholarship and Canadian Forest Products Bursary in Forestry. She was awarded the Board of Governors Prize in Agriculture and Forestry in 1986.

During the summer of 1988 , Caroline participated in the Swedish student exchange, working for Domanverket. Besides holding various teaching assistantships while

\section{Poster Session}

Preceding the FILS lecture, a research symposium and poster session, consisting of over 25 posters, was held. Current research activities within the Forestry Program, ranging in topic from mycorrhizae to bird watchers, were highlighted. The event was well attended and will likely become an annual event.

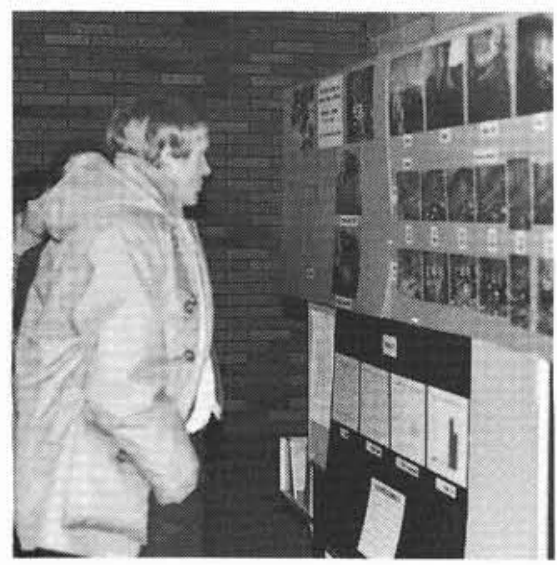

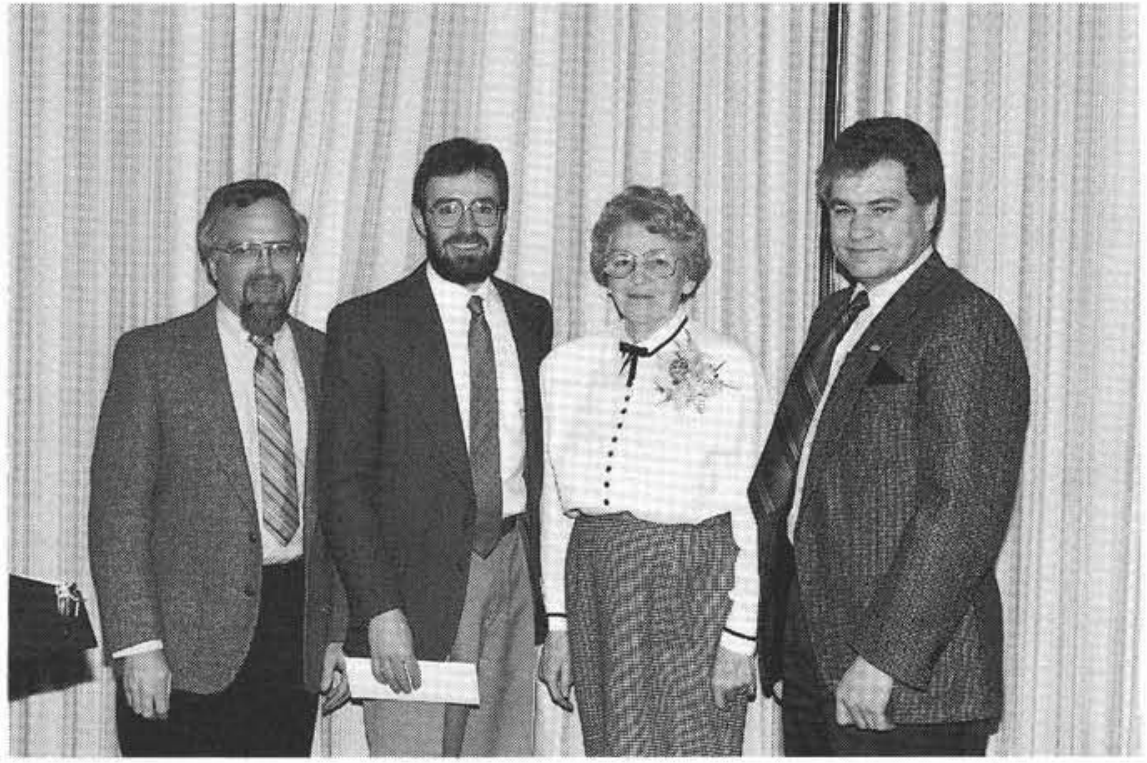

Drs. Ross Wein, Ph.D. Co-Supervisor (right) and Bruce Dancik, (left), Chairman, Scholarship Committee assist Mrs. Isobel Crossley in the presentation of the Desmond I. Crossley Memorial Scholarship to Mr. Rob Wright. 


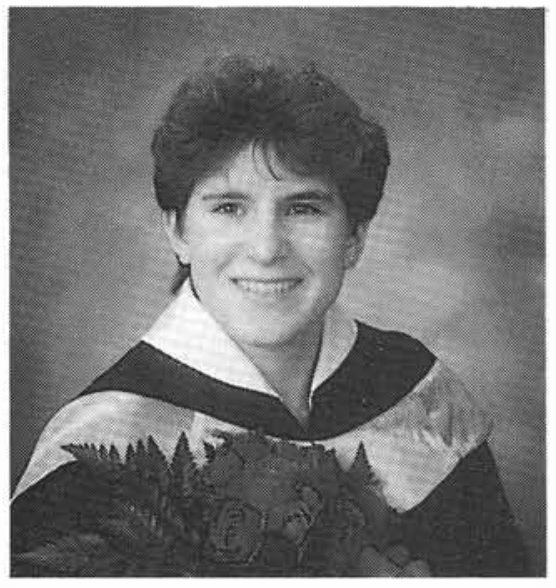

Ms. Caroline Kutash, 1989 University of Alberta recipient of CIF Gold Medal.

attending University she was also heavily involved with school children through the Alberta Forestry Association's Forever a Tree program.

Caroline was presented with the medal by second Vice-President Harry Gairns on the occasion of the CIF Ring Ceremony.

\section{Graduating Class:}

Thirty-one (27 males and 4 females) forestry students celebrated at their recent graduation banquet. Guest dinner speaker. Don Laishley (Weldwood of Canada Ltd.) and Forestry Program staff all wished the 1989 graduating class best wishes in their future endeavours.

\section{Alberta Alumni Foresters' Association (AAFA):}

Thirty-three alumni attended a recent luncheon in Edmonton to witness the birth of the new Alberta Alumni Foresters' Association (AAFA). The AAFA by-laws were ratified and an executive elected. Messrs. Doug Krystofiak (Class of '78) and Gary Dolynchuk ('76) were elected as President and VicePresident, respectively. The remainder of the executive will consist of representatives from the Faculty (Dr. Jim Beck, Chairman), undergraduates (fourth year student appointed by The Forest Society), and a graduate student (appointed by the Forest Science Graduate Student Association). Barbara Chaffey (Alumni Affairs) will act as Secretary/ Treasurer.

A membership drive will commence immediately and I urge all Forestry Alumni to contact the Department if they have not been receiving our past Newsletters. The major aim of the AAFA is to promote the fellowship and welfare of the Forestry Program. Please keep in touch.

\section{Staff Activities}

Dr. Paul Woodard continues his research to assess lichen regeneration rates in Alberta following various types of logging disturbance and wildfire as it relates to woodland caribou. Approximately $\$ 80000$ in financial support has been granted jointly by: Weldwood of

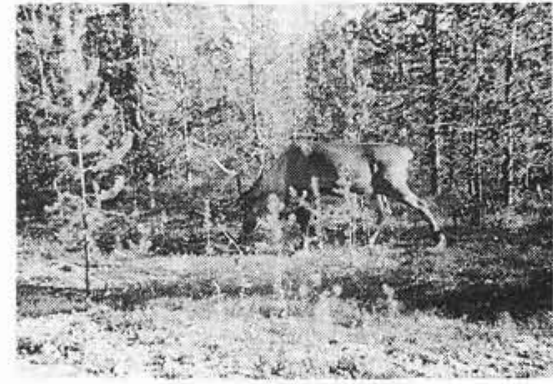

Canada Limited, Hinton Division; Alberta Fish \& Wildlife Division; The Alberta Forest Service; Alberta Recreation, Parks \& Wildlife Foundation; and Wildlife Habitat Canada.

Dr. Joan Snyder, Biologist, Grande Prairie Regional College and Ms. Jan Edmonds, Alberta Fish \& Wildlife Division will join Paul as principal researchers, on this important wildlife issue. The woodland caribou is an endangered species in Alberta. This study is but one attempt to insure the survival of this animal in Alberta.

Doug Krystofiak, R.P.F.

\section{Toronto}

\section{NORANDA/NSERC Industrial Research Chair in Seedling Physiology}

Noranda Forest Incorporated has agreed to provide $\$ 600000$ over a five-year period towards the funding of the Noranda/NSERC Industrial Research Chair in Seedling Physiology, established under the Industrial Research Chair Program of the Natural Sciences and Engineering Research Council. The objective of this program is to assist universities in building on existing strengths and stimulating research on topics of industrial importance.

The funding will permit the Faculty to attract a senior research scientist who will work closely with staff at the University and strengthen linkages between the Faculty and the forest sector in the area of enhanced survival and growth of seedling stock. This forms part of the Faculty's strategic plan to direct a substantial portion of its research effort into the general area of forest health.

\section{Faculty Staff}

\section{Forest Management Position}

Professor Keith Belli, Assistant Professor in Forest Management, has resigned effective 31 July 1989 to return to the United States. He has been appointed since January 1987. The Faculty is now searching for a replacement for September 1989.

Assistant Dean, Research

Professor D.C.F. Fayle has been appointed Assistant Dean, Research, effective 1 May 1989 to 30 June 1991. Dr. Fayle has been with the Faculty as Associate Professor of Silviculture since August 1987

\section{Earth Sciences Centre}

The University's new Earth Sciences Centre, which will house the Faculty of Forestry and the Departments of Botany and Geology, is near completion. Forestry's move is taking place in early June 1989. The new address for the Faculty is: Faculty of Forestry, University of Toronto, Earth Sciences Centre, 33 Willcocks Street, Toronto, Ontario M5S 3B3

\section{Renewal Celebration}

Due to construction delays in the Earth Science Centre, Forestry's opening festivities, originally planned for June 1989 , have been postponed. The Renewal Celebration will now take place from Friday, October 20th to Friday, October 27th, 1989.

Festivities will include the "Spirit of the Woods" exhibit consisting of about 60 handcrafted wood pieces, including sculpture, furniture and jewellery from across Canada. Most of these items will be auctioned on October 27th. The exhibit also includes original paintings by Robert Bateman and by Robert Ross, one of Bateman's students. The exhibit, open from October 20th to October 27 th, will be widely advertised and will be open to the public. Robert Bateman will be present at the opening ceremonies.

The tentative program for the week is:

Friday, October 20th - Opening ceremonies ESC Forestry Wing, opening of the "Spirit of the Woods" exhibit, unveiling of Commemorative Wall, hospitality and guided tour of the art exhibit.

Saturday, October 21st - Open House for alumni, University community, secondary school teachers and students, and the public. The Open House will focus on the Faculty's undergraduate and graduate research programs, but will include many other displays and films.

Sunday, October 22nd - Open House.

Wednesday, October 25th - E.B. Eddy Distinguished Lecture 1989. Lecturer: K.A. Armson, R.P.F., Forestry Consultant.

Thursday, October 26 th - E.B. Eddy Distinguished Lecture 1989. Lecturer: J.F. Shaw, Managing Director and Chief Executive Officer, Canadian Wood Council.

Friday, October 27th - Hospitality and auction of wood-crafted works.

\section{Natural Resources and the Global Environment: A Look to the Future}

Part of the University celebrations accompanying the opening of the new Earth Science Centre building, will be a series of evening lectures, coordinated by the Departments of Botany and Geology and the Faculty of Forestry, entitled "Natural Resources and the Global Environment: A Look to the Future". There will be opening symposia on three successive evenings, - October 16th, October 17 th, and October 18th, from 20:00 to 22:00 hours. Successive lectures will be presented bi-weekly, commencing November 1st. Dr. J. Maini, Assistant Deputy Minister, Forestry Canada, will be the forestry keynote speaker on October 17 th

Ursula Cattelan

\section{New Brunswick}

\section{Faculty of Forestry and Valley Forest Products Ltd. Sign Agreement}

A strategy to ensure the wise resource 


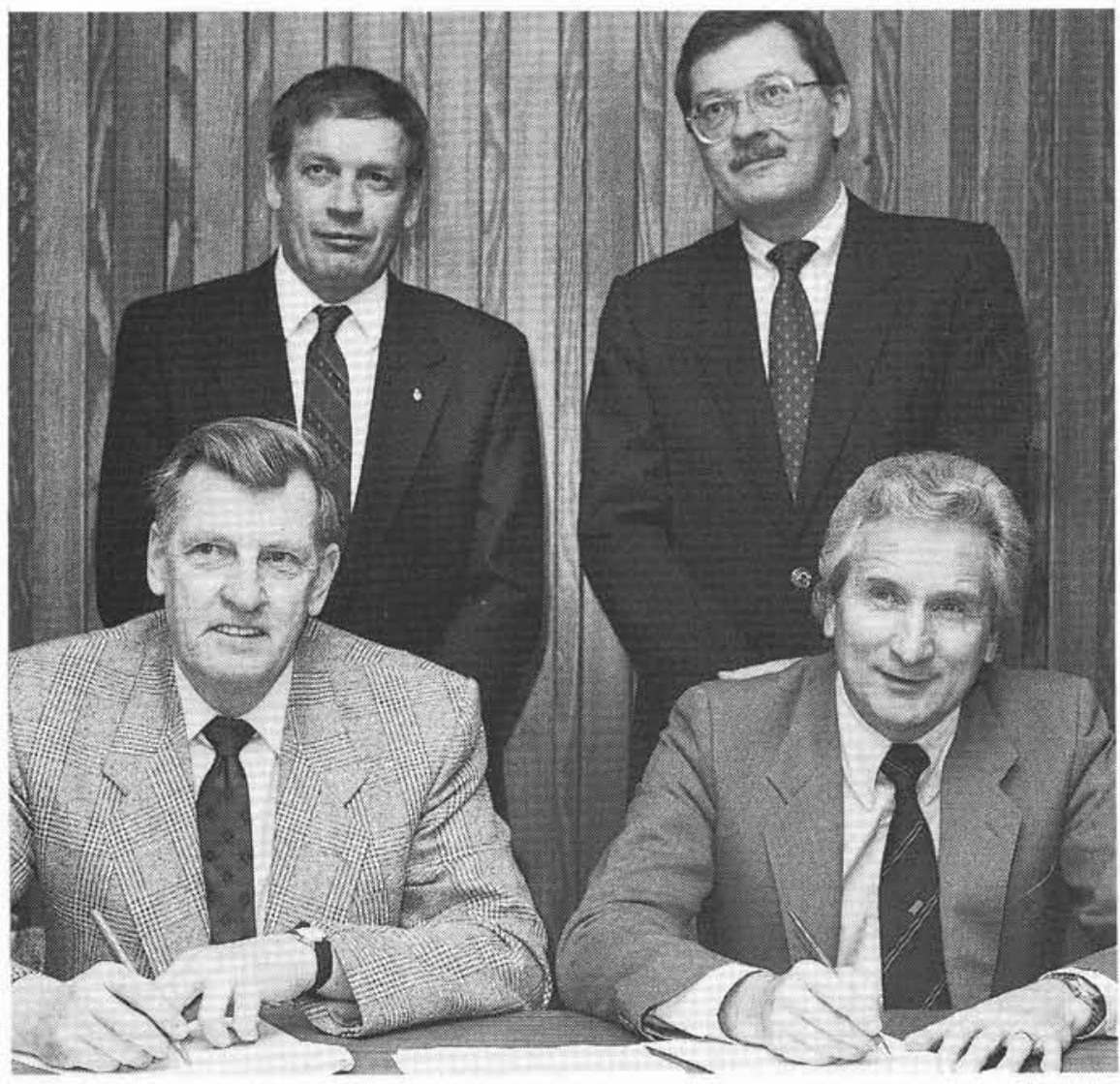

AGREEMENT SIGNED - Valley Forest Products Ltd. and the University of New Brunswick have signed a three-year agreement to develop a resource management strategy for 100000 acres of the company's private lands. Signing are Cliff Hartley (seated left), vice-president, woodlands, on behalf of Valley Forest Products and James Downey, president of UNB. Also at the signing are David Daugharty (left) of UNB's department of forest resources and Tim Easley, department chairman. (W.L. Staples photo).

management of 100000 acres of private forest land in the Canterbury, N.B., area will be developed over the next three years. The UNB Faculty of Forestry and Valley Forest Products Ltd. of Nackawic, N.B., have signed an agreement to initiate the integrated forest management of that company's private lands. "This agreement is an example of the relevance of university research to the management of private industry," said James Downey, president of UNB. "While technology transfer is important, so too is the transfer of resource management research findings."

Under the $\$ 60000$ agreement, scientists and managers from the UNB Faculty of Forestry will conduct research and advise Valley Forest Products Ltd. on the wildlife, recreational, esthetic and environmental management of their private lands. Faculty members will work with the professional and technical staff of Valley Forest Products Ltd. to develop plans at the strategic, forest management and operational levels.

"We definitely need to consider all of the forest resources, including wildlife, as we manage for future generations," said Cliff Hartley, Vice-President of Woodlands for Valley Forest Products Ltd. "We hope, in time, to help small woodlot owners manage the wildlife on their land through an extension of this agreement."
Work on the first stages of the management project outlined by the agreement will commence immediately.

"Valley Forest Products Ltd. deserves credit for their interest and initiative in developing truly integrated resource use on their private lands," said Tim Easley, chairman of UNB's Department of Forest Resources. "This socially conscious action will ensure that the wildlife, recreational and esthetic reserves will be given every consideration within an industrial forest resource base."

Valley Forest Products Ltd. is the woodlands branch of Saint Anne-Nackawic.

\section{Forest Engineering Student Wins UNB Competition}

First prize in the 1989 Engineering Student Paper Competition at the University of New Brunswick has been awarded to Eric VanWalsum of Pointe Claire, Que. Mr. VanWalsum, a forest engineering student, was presented the $\$ 200$ prize by Jim Piercy on behalf of the Association of Professional Engineers of New Brunswick.

Mr. VanWalsum's senior paper was chosen from among the best in the forest engineering department before being entered against the top papers from the six other engineering programs on the Fredericton campus.

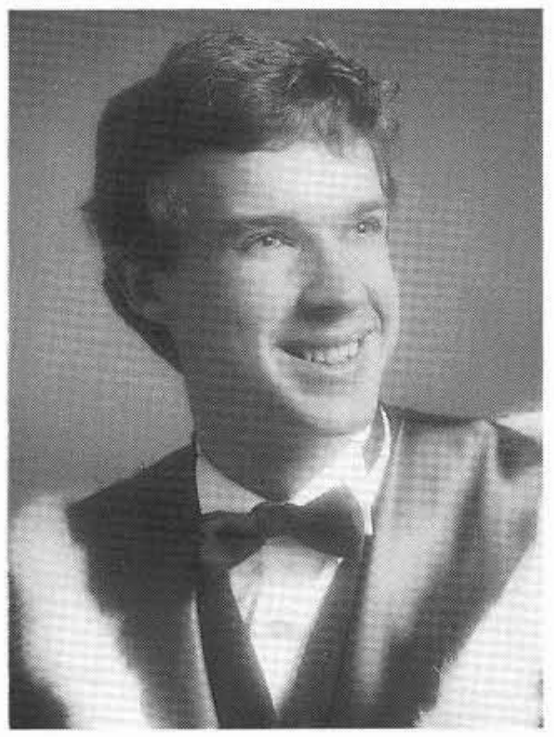

Eric VanWalsum (Photo credit: The Little Studio)

The paper entitled "The Applicability of a Soil Traction Prediction Equation to the Measurement of the Draw-bar Pull Requirements of a TTS-35 Scarifier" examines the use of an empirical equation in measuring the force needed to pull forestry equipment over the ground.

This is the second time that a forest engineering student has won first prize. Dave Kusnierczyk, now with Proctor and Gamble Cellulose Ltd., captured top honors in the 1987 competition. Mr. VanWalsum will receive his bachelor's degree in forest engineering at UNB's 160th Encaenia in May. $\mathrm{He}$ has already accepted a position in development engineering with the Newfoundland Department of Forestry.

\section{New Journal for Forest Engineers}

Prof. E.J. Rickards, chairman of forest engineering, has initiated a new journal in an attempt to integrate the subdisciplines of forest engineering. The Journal of Forest Engineering is devoted to the dissemination of scientific knowledge in all areas related to forest operations. The first issue of this international journal will be published in July, 1989.

\section{Sabbatical Leaves}

Dr. R.A. Douglas and Prof. E.W. Robak, both of the Department of Forest Engineering, are on sabbatical. Dr. Douglas is spending four months with the UK Forestry Commission in Edinburgh, Scotland. Before returning to Canada in September, he will travel to Kuala Lumpur in Malaysia to complete an International Development Research Council project on bamboo reinforcement of unstable slopes. His six-month sabbatical ends Dec. 31.

Prof. Robak began his year-long sabbatical by participating in the planning meeting for the 1990 IUFRO World Congress in Holland. $\mathrm{He}$ will then travel to Ireland to work on a planning systems project with the Irish Forestry Service and the Department of Forestry at the University College of Dublin. He will then work on a similar project in Sweden with 
the forestry school at Garpenberg and a forestry cooperative. Prof. Robak's next stop is New Zealand where he will install and explain the OP-Plan system. He then plans to work on a project to integrate long- and short-term planning using Geographic Information Systems at the Australian National University in Canberra. A visit with the forestry service and forestry school in Malaysia will precede his final stop in Japan. Prof. Robak intends to work with the Department of Forestry at Nagoya University in Japan and the Japanese Forestry Service to develop an integrated forestry planning system. His sabbatical officially ends June 30, 1990.

\section{Paper Published}

Scheiner, S.M., T.L. Sharik, M.R. Roberts and R. Vande Kopple. 1988. "Tree density and modes of recruitment in a Michigan pinehardwood forest after clear-cutting and burning." Canadian Field Naturalist 102: 634-8.

\section{Faculty Briefs}

Dr. I. Smith participated in a US Forest Products Laboratory Workshop on research needs in structural timber connections, in Portland, Oregon on March 15 and 16. From May 29 to June 6. Drs. Smith and Y.-H. Chui visited the Instituto Forestal in Santiago, Chile as part of an International Development Research Council project on wood construction.

Dr. G.R. Powell gave a presentation, entitled "Bud development and shoot extension in balsam fir: knowing the processes helps in making treatment decisions," at the Spring Technical Session of the Northeastern Christmas Tree Association in Antigonish, N.S.

Prof. R.B.B. Dickison served as session chairman during the 10th Conference on Fire and Forest Meteorology in Ottawa, Ont., April 17-21.

Dr. M.S. Jamnick presented a paper at the COR/TIMS/ORSA Joint National Meeting in Vancouver, May 8-10. It was entitled "Influence of land classification systems on timber harvest scheduling models."

Prof. D.A. Daugharty was the chief Canadian delegate at the International Hydrological Sciences Third Scientific Assembly in Baltimore, Maryland, May 10-19. He attended the Eastern Snow Conference in Quebec City, June 8 and 9 , as past-president and he chaired the annual meeting of the NRC's Associate Committee on Hydrology in Wolfville, N.S., June 21-23.

Prof. E.J. Rickards presented a paper, entitled "Application of the Gamma Distribution to the study of labour productivity in maintenance operations," at the Institute of Industrial Engineers' annual conference in Toronto, May 15-18.

\section{Continuing Education}

\section{Upcoming Courses}

1. Identification of Shrubs and Ground Vegetation of Importance to Forestry in New Brunswick, Aug. 22 and 23.

This workshop will help foresters and technicians involved in site classification to identify common forest plants. Identifica- tion will be based on easily visible features of the plants - not minute features or botanical descriptions. Registration deadline: July 21. Location: Maritime Forest Ranger School, Fredericton, N.B.

2. A Conference on Forest Production, October 22-28.

The purpose of this conference is to assist decision makers in developing their abilities to plan, and to execute their plans, in the changing environment of forest land use. The conference is aimed at those who are responsible for managing landuse problems. It will provide participants with the rare opportunity to discuss their ideas with their peers in an unstructured and confidential setting. Registration deadline: Aug. 4. Location: New Brunswick and Maine. The Hugh John Flemming Forestry Centre in Fredericton will be the base of operations.

Brochures on these two courses are available from the coordinator of continuing education in forestry at the address below.

\section{Forestry Focus}

The Spring 1989 issue of the UNB Forestry Focus is entitled "The role of insect behavioural ecology in forest pest management".

The author is Dan Quiring, an entomologist with the UNB Department of Forest Resources. He maintains that one of the largest obstacles to the effectiveness of pest management programs is a lack of understanding of the behavioural ecology of pest insects. He presents examples demonstrating how studies of the behavioural ecology of forest insect pests can improve the efficacy of pest management procedures and permit better predictions of the long-term utility of different management techniques.

Copies of the UNB Forestry Focus (Vol. 14 No. 2) are available from the Coordinator of continuing education in forestry.

Coordinator, Continuing Education in Forestry, University of New Brunswick, Bag Service \#44555, Fredericton, N.B. E3B 2C1, (506) 453-4501

\section{- Sandra Howland}

\section{British Columbia}

\section{Faculty News}

Forest Resources Management Department. Prof. F.L.C. Reed, NSERC Industrial Professor of Forest Policy, was much in demand as a speaker during March and April. He met in early March with the Canadian Forest Minister's Council and spoke on forestry investment. Then he returned to Toronto for a Forestry Canada Forest Communicators Conference. He spoke at the Woodlands Section of the CPPA annual meeting in Montreal. Early in April he spoke at the annual general meeting of the NILS association in Prince George. In mid-April he spoke at Thunder Bay on "Tools for site specific silviculture" and in Ottawa at a Bioenergy Conference. In association with this trip he met with provincial and industrial representatives in Toronto and with federal representatives in Ottawa.
Dr. D.L. Golding had his contract for a water quality study in the Okanagan renewed for $\$ 20,000$ by the BC Forest Service. His special erosion study in the Greater Vancouver Water District was supported by manpower and resources totalling $\$ 10,000$.

Dr. A. Kozak addressed the meeting of FERIC on Research Management at Parksville, April 26 . He described the number of samples required for statistical decisions.

Dr. P. Marshall completed a report on the economic value of additional information about response of coastal Douglas-fir to stand treatments for FEPA. He joined the Board of Examiners of the Association of British Columbia Professional Foresters and continued to serve the Faculty on the B.C. growth and yield technical advisory committee. He lectured on stand dynamics at the Silviculture Institute of B.C.

Dr. P. Dooling presented a brief to the Minister of Forests as part of the hearings on conversion of forest licences to tree farm licences. He also hosted several visitors and represented the Forest Resources Management Department in the search for a joint appointee in Landscape Architecture and FRM.

Dr. P.A. Murtha was actively involved in the GIS '89 program March 8-10 in Vancouver. April 14 he met with the Canadian Remote Sensing Society in Ottawa and had discussions with scientists from the Canada Centre for Remote Sensing. The UBC Forestry Sensing Laboratory (FIRMS, Forest Information for Resource Management Systems) received another boost. $\mathrm{Dr}$. Murtha was awarded a $\$ 300,000$ grant by the B.C. Science and Technology Development fund for "GIS Integration in the Forestry Faculty". Several INTEGRAPH workstations will be installed in Forestry and Ethernetted to another installation in Geography. When installed, the teaching Lab. will be running four types of GIS software and two varieties of image analysis software. He presented a paper at the 12th Workshop: Air Color Photography in the Plant Sciences in Reno Nevada, entitled "The vegetation index and a multitemporal data set from CIR photos". In February, Dr. Murtha participated in the Forestry Canada program review assessment team, evaluating "Forest Management Systems".

Dr. Valerie Le May joined the Department of Forest Resources Management January 1. 1989 to teach and do research in the area of Forest Mensuration. She holds B.Sc. and M.Sc. degrees from the University of Alberta and a Ph.D. from U.B.C. Her 1988 thesis was a comparison of fitting techniques for systems of forestry equations.

Dr. Thirgood had an active fall term with 14 students in his elective International Forestry course, 5 Master's candidates and 3 Ph.D. candidates in residence, direction of a major wastewater/poplar project in Vernon, and active involvement in Municipal Public Hearings on the future of Terra Nova in Richmond. He has been involved in a weekly "spot" on local history and land use issues for TV Channel 4. He completed a report "Forests and Forestry in the Near East, a conceptual framework for forestry educational and training" commissioned by FAO for its Advisory Committee on Forestry Education.

Dr. J.H.G. Smith presented two papers at the Western Forestry and Conservation 
Association meeting in Seattle, Washington, December 5-7, 1988. He described an overview of pruning and implications for management from several Northwest spacing trials.

\section{Postgraduate Degrees}

The following eight M.F., three M.Sc. and five Ph.D. degrees were completed during 1988/89.

ABDUL MALEK, I. (Non-thesis program in Forest Harvesting). M.F. (A.F. Howard).

BIGLEY, R. Ecological physiology of conifer seedling and sapling suppression by, and release from, competing vegetation. Ph.D. (J.P. Kimmins).

GREEN, R. Site-forest productivity relationships and their management implications in coastal lowland ecosystems of East Graham island, Queen Charlotte Islands. M.Sc. (T.M. Ballard).

HUANG, S. Continuous forest inventory using multistage unequal probability sampling with partial replacement. M.F. (P.L. Marshall).

KHETARPAL, S. Use of benefit cost analysis with equity considerations to evaluate social forestry projects in India. M.Sc. (J.H.G. Smith).

KREMSATER, $L$. Influences of habitat interspersion on habitat use by blacktailed deer. M.Sc. (F.L. Bunnell).

LEMAY, V. Comparison of fitting techniques for systems of forestry equations. Ph.D. (A. Kozak).

McGEE, A. Vegetation response to rightof-way clearing procedures in coastal British Columbia. Ph.D. (M.C. Feller).

MUNGURE, F. Some gluing characteristics of Ocotea usambarensis (Engl.) M.Sc. (L. Paszner).

NGUSYA, M. Aspects of eucalyptus waferboard. M.Sc. (L. Paszner).

PENNER, M. Optimal design for linear regression with variable costs and precision requirements and its applica- tions for forestry. Ph.D. (J.P. Demaerschalk).

SALOM, S. Dispersal and flight behaviour of Trypodendron lineatum (Olivier) (Coleoptera: Scolytidae) as influenced by semiochemicals and environmental factors. Ph.D. (J.A. McLean).

SCHADENDORF, C. (Non-thesis program in Forest Economics). M.Sc. (D. Haley).

SCHULTING, M. The genetics of disease interaction in the lodgepole pine: Western gall rust host: parasite system. M.Sc. (B.J. van der Kamp).

TAVIS, I. (Non-thesis program in Forest Policy). M.Sc. (F.L.C. Reed).

VON DER GONNA, M. First year performance and root egress of white spruce (Picea glauca (Noench) Voss) and lodgepole pine (Pinus contorta Dougl.) seedlings in mechanically prepared and untreated planting spots in North Central British Columbia. M.F. (D.P. Lavender).

\section{SUSTAINING MEMBERS OF CIF/IFC, 1988}

Each year the institute takes great pleasure in publishing the names of its Sustaining Members. There are two kinds; those individual members of the Institute who voluntarily subscribed an additional $\$ 30.00$ or more above and beyond their normal dues; and, secondly, corporate members who subscribed a minimum of $\$ 200 / y e a r$.

\section{Individual Sustain Members}

A. Brookman Anderson

H.W. Beall

Al Best

A. Bickerstaff

J.W. Bird

M.P.M. Broeren

Brian Cardwell

Kevin M. Carvill

J.H. Cayford

T.M. Charles

J.D. Coats

E.S. Fellows

G.J. Garner

G.G. Gray

R. Grinnell

D.L. Handley

A. Kabzems

D.D. Lockhart

J.D. MacArthur

D.A. MacLulich

V.J. Nordin

David Parker

H.A. Peacock

D.R. Redmond

J.O. Smith

A.M.D. Todd

D.G. Tomlin

J.R.M. Williams

\section{Corporate Sustaining Members}

A\&L Lafreniere Lumber Ltd.

Chapleau Forest Products Ltd.

Equipement Denis Inc.

Canadian Forestry Service

Northwood Mills Noranda Sales

St. Marys Paper

United Brotherhood of Carpenters \& Joiners

Woodlands Section, Canadian Pulp and Paper

Association

The Institute is most appreciative of the support of its sustaining members.

C. Godbout

President

\section{Back Issues of Forestry Chronicle Required}

The Institute Head Office requires the following issues of The Forestry Chronicle. We will pay postage for any copies forwarded; contact $\mathrm{HO}$ first.

Vol. 40, 1964, March

Vol. 50, 1974, October

Vol. 51, 1975, August

Vol. 53, 1977, All Issues

Vol. 54, 1978, June, August, October

Vol. 55, 1979, February, June, August

Vol. 56, 1980, June, August, October, December

Vol. 59, 1983, October

Vol. 61, 1985, April, June, August, October, December

Vol. 62,1986 , February, June

Vol. 64, 1988, August

J.H. Cayford, R.P.F. Executive Director 